\title{
The Mon Paradigm and the Origins of the Burma Script
}

SINCE THE CONQUEST of Thatôn is not mentioned anywhere in the original epigraphy of Burma, and does not appear in the chronicles until, at best, the sixteenth century, the consequences that have been attributed to it - the heart of the Mon Paradigm-are all now open to question. These include the notion that the Mon of Lower Burma provided the kingdom of Pagán with its writing system, literature, religion, art, and architecture, along with components of its conceptual system and other cultural and technological achievements. Further analysis of most of these subjects I will leave to scholars in the appropriate disciplines, but in this chapter I shall address one of the most important claims: that as a direct result of Aniruddha's conquest of Thatôn, Pagán—and hence Burma—received its writing system from the Mon of Lower Burma, who in turn had obtained it from Dvāravatī. ${ }^{1}$

But since the conquest of Thatôn is no longer defensible, why does the issue of the script need to be addressed at all? The reason is the same as that in the previous two chapters: if the Mon Paradigm is to be convincingly dispelled, it is not enough simply to show that the Thatôn conquest is not historically viable, the thesis regarding the script still needs to be disproved and a more viable option offered, for if the Burma script did not come from the Mon of Dvāravatī via Thatôn, scholars will still want to know from where it came.

This chapter will attempt to trace the possible origins and development of the Burma script, while describing how the topic evolved within Burma Studies. I will demonstrate that no contemporary epigraphic or historical evidence exists to support the contention that the Pagán (hence) Burma script was derived directly or indirectly from Dvāravatī via Thatôn and will discuss the major scholars and their particular involvement in the topic. The conclusion reached here again reverses the Mon Paradigm: that Burma's Old Mon script derived from the Old Burmese script. 


\section{The Major Issues}

The origins of the Burma script itself is still an unresolved issue, and since I am neither a linguist nor a paleographer, my main purpose here is not to resolve problems directly related to linguistics or paleography-although the latter is an integral part of epigraphy and so will be an important feature here-but to raise some historical and evidentiary questions that have a direct bearing on the subject.

There are some points on which all agree. First, the script used for both Old Burmese and Old Mon during the Pagán period, what I call the Burma or Pagán script, is "practically identical” except for two letters. ${ }^{2}$ Second, the ultimate source for this script is South India. And third, the Burma script was apparently not derived directly from South India but through an intermediary. And herein lies the heart of the controversy. Who was the intermediary-the Pyū of Burma or the Mon of Dvāravatī? ${ }^{3}$

More specifically, is the Burma script a version of the Mon Dvāravatī script that is said to be based on the Old Tamil Pallava script of Kãñcipuram in Southeast India, ${ }^{4}$ or is it taken from the Pyū script, which is itself derived either from the Kadamba of Vanavasi in Southwest India or the scripts of Andhra in Southeast India? ${ }^{5}$ Since the conjectured sixth- to eighth-century Mon Dvāravatī script of Old Siam is considered to be "very different from the fourth to seventh-century Pyū script of Halin and Śrī Kṣetra," ${ }^{6}$ while the Burmese and Mon scripts of eleventh-century Pagán are "nearly identical," 7 only one is likely to be the source for the Burma script, not both.

In addition to demonstrating the source paleographically, we must also show how and when transmission of the script occurred. To be historically tenable, the transmission should be chronologically sound, and there must be ample opportunity for such cultural borrowing to have taken place. For its part, the paleographic evidence should graphically exhibit at least an affinity between the source and the final product, based on actual, dated examples, not just on a conjectural reconstruction, despite the fact, as de la Vallée Poussin so aptly remarked, paleography is "une petite science conjecturale."

We need to be cautious, therefore, with paleography, for although it may suggest a probable relationship of scripts, it can be quite misleading if it is not corroborated by authentic dates derived from the same records under scrutiny. This is especially true when dealing with scripts that changed very little over long periods of time, such as the Pyū, Burmese, and Burma Mon scripts. ${ }^{8}$ Although this is a complicated issue that perhaps only philologists and paleographers should address, I can, as a historian, still assess whether either of the two origins scenarios has any merit in terms of epigraphic and other historical evidence. 
It is important to realize from the outset that there has never been a formal scholarly debate on the origins of the Burma script that has been published in English. Nonetheless, the published literature has generally fallen into two schools of thought, which are more the result of individual studies than any concerted attempt on the part of those involved to make their own positions distinct from those of others. In that sense the debate is somewhat artificial, since it is something I have reconstructed from the existing literature. But that does not mean the actual scholarship and the differences in opinion are any less genuine or valuable. It should come as no surprise that one school reflects the Mon Paradigm and its position that the Burma script came from the Mon of Dvāravatī, while the second, which originally consisted of only one scholar, suggests that the Pyū culture was the likely source for the Burma script.

\section{The Mon Connection}

There are three possible, theoretical sources for a Mon connection: Thatôn, Dvāravatī, and Haripuñjaya.

\section{THATÔN}

Although Forchhammer may have been the first to suggest in a general way that the Pagán script probably had Lower Burma Mon origins, it was Duroiselle who first made a scholarly and systematic case for it. In the first issue of Epigraphia Birmanica published in 1919, Duroiselle noticed the similarity of the Burmese and Mon alphabets and wrote that they were nearly identical except for two letters. This led him to conclude that "one of the two nations borrowed its alphabet from the other." ${ }^{9}$ One can immediately see a problem of analysis, for both cultures could have borrowed the script from a third party rather than from each other. In fact, Blagden briefly hinted that this was a possibility, that the Pyū might have been the source, but he never pursued the issue. Given the state of knowledge regarding the Pyū in 1919, as well as the intellectual trend supporting the view that the Burmans borrowed virtually everything from the Mon, Duroiselle's analysis and conclusions, in hindsight, are neither surprising nor extraordinary.

Duroiselle then speculated that the historical event, the mechanism for this borrowing, was the conquest of Thatôn by Aniruddha, and herein lay the most egregious flaw. He wrote: "All evidence tends to show that the Burmese received their alphabet from the Mons about AD 1057. It is in that year that Anorata, king of Pagán, swooped down upon the deltaic provinces of Burma, that is, Rāmañnadesa, the Talaing country, and after a siege of three months, entered Thatôn, the capital." As proof, Duroiselle offered 
the following: "No inscription whatsoever in Burmese or Pali has yet been found at Pagán antedating Anorata, ..." and "it is from that time that writing was adapted to common use by the adoption of a foreign alphabet to represent Burmese sounds. ..." ${ }^{10}$ So once again the foundations of the analysis returns to the catch-all cause-the conquest of Thatôn-the keystone of the Mon Paradigm.

Yet, just two years later, Duroiselle published a valuable reference called A List of Inscriptions found in Burma in which he enumerated approximately nineteen Burmese and Pali inscriptions that predated Aniruddha's reign. ${ }^{11}$ Although he could have qualified what he had written earlier in 1919_ that "no inscription whatsoever in Burmese or Pali has yet been found at Pagán antedating Anorata ... "- -he did not. Instead, he obfuscated his original position further by stating that the "principal alphabets" of Burma (including Pyū, Mon, Burmese, and Shan) were based on the Old TeleguCanarese alphabets of South India. ${ }^{12}$ But, he continued, whereas the Pyū script was influenced directly by the Kadamba script of Vanavasi in North Canara, as was the Mon script by the Pallavas of Kāñcipura, the Burmese and Shan scripts were derived indirectly from Mon. ${ }^{13}$

The statement about the Burmese and Shan scripts was not only unnecessary and speculative-without any paleographic support or historical explanation as to how that might have occurred-it also appears to be a contradiction. On the one hand, he had said the "principal alphabets" of Burma, including Mon, were based on the old Telegu-Canarese alphabets, but on the other, that they came (although indirectly) from the Pallava of Kāñcipura via the Mon. However, these two scripts-Old Telegu-Canarese of Vanavasi, by which Duroiselle later meant Kadamba, ${ }^{14}$ and the Pallava of Kāñcipura-were quite different, particularly if we are dealing with the Pallava script, which was nearly 300 years later in time and almost as many miles apart geographically in South India. ${ }^{15}$

And since the Śrī Kṣetra Pyū and Mon Dvāravatī scripts are "very different," as Luce noted-suggesting that the comparison was indeed being made with the later Pallava script-while the Burmese and Mon scripts of Pagán are "nearly identical," about which all agree, how do the "very different" parent scripts end up producing "nearly identical" offspring? Perhaps it is linguistically possible, but it was never explained or demonstrated by either Luce or Duroiselle.

Duroiselle's "direct" and "indirect" influences are at the heart of the obfuscation, not least because he allowed only one "indirect" influence, that of the Mon, thereby, steering research away from another perfectly viable option that should have been considered as well: namely, the Pyū. Indeed, Duroiselle's Epigraphia Birmanica-founded most probably for scholarly 
purposes although I would not doubt some political influences working on the whole process-became the mechanism for maintaining that research direction in which the Mon were the focus of attention. In a word, both the analysis and conclusion regarding the origins of the Burma script had once again assumed the historicity and antiquity of Rāmaññadesa and the viability of the conquest of Thatôn.

One could argue that Duroiselle's position in 1919 (or in 1921) was not entirely unreasonable since in part it may have resulted from the lack of good data on the Pyū alternative. Yet in the late nineteenth century U Tun Nyein had discovered the Maung Kan gold plates with Pyū writing on them, while Louis Finot had by 1912 published his thoughts on that script as having been derived from southwest India. ${ }^{16}$ And it was through the labors of Duroiselle himself, ${ }^{17}$ as director of the Burma Archaeological Survey, that much additional information on the Pyū emerged, while their language had been deciphered by Blagden nearly a decade earlier. ${ }^{18}$ Admittedly, during Duroiselle's time, there were no radiocarbon dates or modern excavations that pushed the Pyū urban culture back to the second century BC. But nearly all the evidence for the Pyū writing system was already available. The real problem was that no one considered even the possibility of a connection between the Pyū and Pagán scripts because the Mon Paradigm was so intellectually overwhelming and entrenched. ${ }^{19}$

Ultimately though, the problem was inherent from the start: it lay in the tautological nature of Duroiselle's initial assumption. In 1919 he wrote: "If it is considered that the Talaing and Burmese characters at that time [the Pagán period] were identical, and that the greater antiquity of Talaing civilisation is accepted on every hand, I think the rational conclusion is that the Burmese borrowed their alphabet from the Talaings ..." [my emphasis]. ${ }^{20}$ Here is the ultimate basis for his thesis: the belief in the "greater antiquity of Talaing civilisation on every hand." That premise, as is demonstrated throughout this book, had become proof.

Even prima facie, Duroiselle's thesis that the Burmese borrowed its alphabet from the Mon after 1057 cannot stand scrutiny. Are we to believe that for nearly 150 years after the founding of a capital city whose kingdom was to rule the country for another five hundred years that the Burmese speakers still had not adopted a writing system for their vernacular? And this even after as long a period of contact with, and absorption of, the culture of the literate Pyū people and long after the alphabets of North and South India had arrived and had been in use in the society? ${ }^{21}$ Are we to believe that only after the Burmese speakers had conquered some Mon refugees presumably living here and there in Lower Burma, that they immediately and suddenly waxed eloquent in hundreds of Old Burmese inscriptions? 
Duroiselle's argument also implies that Aniruddha's grandfather, Saw Rahan, his father, Kyaung Phyu Min, and Aniruddha himself were all illiterate in Burmese. If this were so, how did they communicate with the obviously Burmese-speaking majority in order to administer their large and rapidly growing kingdom for the century and a half prior to 1057 ? How were royal orders issued, tax records maintained, people registered, laws implemented, and rituals of state conducted? Certainly not verbally, or in Sanskrit and Pali, the language of the elite clergy.

Beyond the domestic requirements for literacy, how did the Pagán kingdom communicate officially with other states, such as Sung China, to which it sent an embassy in 1004 AD, ${ }^{22}$ half a century before allegedly knowing how to write in their own language? Did the ambassador go to the Sung capital without any written communiqué so that diplomatic relations with foreign states, even one as important as China, were also conducted verbally? This is not likely, especially as we have evidence that the Sung replied in writing, so that perhaps we can assume that the Pagán court even had knowledge of, or access to translating written Chinese. ${ }^{23}$ Missions were sent to India as well, one in 1035 and two in 1079 and 1086 (or a decade later), to repair the famous Mahābodhi temple at Bodhgayā, a topic to be discussed in Chapter Eight. ${ }^{24}$ Thus neither prima facie nor external evidence from both China and India supports Duroiselle's thesis that Pagán society was illiterate until after 1057 and the alleged conquest of Thatôn.

Even Old Mon evidence conveniently assigned to Thatôn does not support his thesis. Of the approximately ten Old Mon inscriptions found at or near Thatôn, most are undated, so we do not know to which century, between the eleventh and fifteenth, the language belongs, because, as stated above, the Old Mon writing system in Burma did not change perceptibly during that time. ${ }^{25}$ In addition, only six of the ten stones can be said to have been found in situ, which means the provenance of the rest is unknown and cannot be attributed to Thatôn (which as we saw in Chapter Four never existed anyway). Nevertheless the data from all these inscriptions-two of the most important being the Trāp and Pandit Inscriptions, whose provenance and chronology are also unknown-have been used to argue that an earlier Thatôn version of the Old Mon script existed. Two others, the Kyaik Talan and Kyaik Tè Inscriptions of 1098, were actually erected by King Kyanzittha, ${ }^{26}$ which makes them Pagán, not Thatôn records.

Perhaps most important, all Old Mon inscriptions found at Thatôn were written in the already developed Pagán script: they were not the latter's linguistic precursors. Indeed, there is no such thing as a "Thatôn script" distinct from the Pagán script in the written Old Mon of Burma: they are one and the same. But the Mon Paradigm needed a distinct Thatôn script and an earlier Thatôn kingdom in order to make its case that a previous independ- 
ent cultural and political entity had existed. Without these assumptions, Thatôn's role in Burma's history is reversed: it becomes the entity that received "civilization," including the script, from Pagán. That is very likely the reason Luce contrived the date of 1050 for the Trāp and Pandit Inscriptions, because it meant they would precede Aniruddha's alleged conquest of 1057 . This contention simply cannot be confirmed by original epigraphy.

\section{DVĀRAVATī}

Unlike Duroiselle and his colleagues who were the first generation of pioneers, the next generation of scholars did have much of the data we now have on the Pyū, with the exception of the most recent excavations and the TL and radiocarbon results of their remains. By then, there was ample, even if imperfect, information on the Pyū. The most renowned spokesperson of the second generation was Luce, who had the benefit of the more recent data (he died in 1979), making his assertions more culpable than those of the previous generation.

One of the second generation's "new" discoveries was the Mon kingdom of Dvāravatī, which was introduced to the field of Burma Studies around 1924 by Luce, who based his work on Pelliot and other French historians. ${ }^{27}$ That only reinforced the Mon thesis begun by the first generation. Yet I cannot help but feel that had Luce lived ten more years, he might finally have changed his mind about the debt owed the Mons by the Burmans. His latest research, best reflected by his posthumous work, Phases of Pre-Pagán Burma, seems to have been heading that way.

Luce reconfirmed Duroiselle's 1921 claims that the Burma script was derived from the Mon, but went one step farther by specifying that it was derived from the kingdom of Dvāravatĩ. ${ }^{28}$ Yet he did not explain how and when that might have occurred, nor did he provide any convincing linguistic evidence for that assertion. That is, he did not illustrate even paleographically how the two scripts might have been related. Consequently, there is no analytical or evidentiary basis on which to examine his theory, since he merely asserted his conclusion and then left it for future generations to disprove.

In an article published in $1961^{29}$ Luce had devised a chart which he labeled "Stages of Old Mon Orthography" that provides a glimpse at the factors he likely considered in reaching his conclusion..$^{30}$ In the chart Old Mon words were grouped into four chronological and geopolitical categories covering six to seven hundred years and representing the "distinct kingdoms" of Dvāravatī, Thatôn, Pagán, and Haripuñjaya. Each word was given a period to occupy, and a "journey" of the orthography of approximately thirty-five Old Mon words from eighth-century Dvāravatī to a pre- 
sumed mid-eleventh-century Thatôn kingdom, to twelfth-century Pagán, arriving at last at thirteenth-century Haripuñjaya. ${ }^{31}$

Besides being purely conjectural, this journey has some very serious problems. There is an obvious confusion between language and script, the two so inexorably intertwined that the journey allegedly taken by the Old Mon language was held to be synonymous with that allegedly taken by the script. In fact, these took two entirely different (even if conjectural) paths, as we shall see. That is to say, although the chart is a collection of Old Mon words-and therefore an analysis of language-the title of the chart, "Stages of Old Mon Orthography," clearly states he was thinking about the script as well.

Second, the existence of Thatôn in the eleventh-century has been shown to be mythical, so its place on this chart and the data assigned to it are also spurious. Neither the city nor the data actually existed at the time, so the Old Mon orthography attributed to Thatôn actually belongs to Pagán. To reiterate, there is no such thing as a "Thatôn" Old Mon script that is distinct from the Pagán script. The earliest dated Old Mon inscriptions found at Thatôn are those of King Kyanzittha in 1098, not the Trāp and Pandit Inscriptions. All linguistic data derived from a conjectural eleventh-century Thatôn, said to represent a distinct, second "stage" of Old Mon orthography, actually belongs to the Old Mon language and script of eleventh-century Pagán.

A third problem with this journey is the conjectural dating of both Dvāravatī and its script. Although there is some evidence in the Chinese sources that supports the existence of what is thought to have been a political (or at least a cultural) entity called Dvāravatī in the seventh century, the dates assigned to the script still conform to a predetermined conclusion, as none of the Dvāravatī (Lopburi) inscriptions is dated. ${ }^{32}$ And if, like the Pyū and Pagán Old Mon scripts, the Dvāravatī script also did not change for a long period of time ${ }^{33}$ (as indeed suggested by the virtually unchanging orthography), ${ }^{34}$ there is no assurance from paleography alone that the script on the Lopburi pillar is in fact seventh or eighth century rather than, say, thirteenth century. The only reason we know, for example, that the Pyū script on the Myazedi Inscription is twelfth century is that it is dated; the script itself is virtually identical to that of seventh-century Śrī Kṣetra. ${ }^{35}$ The same, perhaps, can be said of the Lopburi script, especially as no dates appear on the stone.

It comes as no surprise, therefore, that Luce's comparison of the Old Mon orthography of Dvāravatī, Thatôn, Pagán, and Haripuñjaya words shows few differences. He wrote that "nearly all [the words from Dvāravatī] are common to the 11 th century Burma Mon." And that "the spellings ... 
are almost identical." ${ }^{66}$ Such similarity, however, does not imply that the Dvāravatī and Pagán scripts must also be related, or that the former had to be the progenitor of the latter. Without confirmed dates at both ends (of the writing system), there is no way to determine which preceded which.

To complicate the matter, the seventh-century date assigned to the Lopburi script also may have been determined, in part, to coincide with the period when historians think Dvāravatī flourished. And the historians, in turn, had based their periodization of Dvāravatī on the chronology provided by the paleographers. ${ }^{37}$ The Chinese evidence for the entity we think was Dvāravatī ${ }^{38}$ somewhat alleviates the issue of its existence around that time, but the dates assigned to "its" script would still remain unproven.

That the script may be relatively late is suggested by its dissimilarity to the earlier Pallava-Grantha script that was carried by Indians to Southeast Asia in the fourth century AD and used widely. According to Nilakanta Sastri, the Pallava-Grantha script at the time was "little differentiated from the ancestor of modern Telugu-Kannada" ${ }^{99}$ (that is, Kadamba, the source for the Pyū script). And because the Pallava script of Mon Dvāravatì is said to be "very different" from the Kadamba, and hence the Pyū, script, Dvāravati must have only later adopted the changed Pallava script called Vatteluttu (round hand) which first appeared only during or after the eighth century. Although Shorto thinks the Dvāravatì script belongs to the seventh century AD (since it fits its "history"), Guillon, following Diffloth, ${ }^{40}$ dates it to the eighth century probably because of its Vatteluttu look. At the earliest, then, the Lopburi script could be seventh century, but it is not at all certain how late it was still being used.

The point is that although this "backward reckoning" method may have been used successfully by Indo-European linguists dealing with the IndoAryan languages of India, it can create many problems of circularity when there is no secure dating of Old Mon orthography. Indeed, the absence of dates regarding Old Mon epigraphy is a serious problem in general. According to one recent source, of a total of twenty-five Mon inscriptions so far recovered in what is now Thailand, only one of them is securely dated, to 1504. ${ }^{41}$ This means that with that single exception, too late to be of any consequence to the present topic, the dates assigned to all Mon inscriptions in Thailand are conjectural.

Apart from the problems inherent in the journey of Old Mon orthography, the theory that the Pagán script came from Dvāravatī also fails to answer some basic historical questions. How and when that might have occurred has never been explained. I know of no record, primary or secondary, in the history of Southeast Asia that mentions at any time a migration of Mon people from Dväravati to Lower Burma which might have effected that alleged borrowing. 
In fact, any putative Mon migration from Dvāravatī appears to be contradicted by Diffloth's study of Nyah Kur, the direct linguistic descendant of Dvāravatī Old Mon, which is still found in what is now central Thailand. ${ }^{42}$ Its continued presence until today in a region that was thought to have been part of the kingdom of Dvāravati suggests that Nyah Kur speakers did not migrate anywhere, but remained more or less in the same area where they retained their language over the intervening centuries. Indeed, according to present-day Nyah Kur speakers, they "have always been in the area where they are now. . . ." ${ }^{43}$ Even if we assume that some of these people might have migrated elsewhere, there is no evidence, to date, of Nyah Kur's presence in Burma, the issue at hand. Indeed, a chronological map of Old Mon inscriptions on Mainland Southeast Asia drawn by Diffloth reveals no movement to the west of the Salween until the eleventh century. On the contrary, Diffloth's study shows that Dvāravatī Old Mon moved in exactly the opposite direction. From what is thought to have been the heartland of Dvāravatì in the central plain of Thailand, Old Mon went north and east to Chanasa (Canāśapura or Śrī Canāśa), on the Khorat Plateau and from there to Vientiane. The Vientiane inscriptions are dated, paleograpically at least, to the tenth and eleventh centuries AD. ${ }^{44}$ The rest of the Old Mon inscriptions of Thailand have been assigned to the twelfth and thirteenth centuries and later, well after the dated eleventh century Old Mon inscriptions of King Kyanzittha, and therefore suggest a process that was just the opposite, as we shall see below. ${ }^{45}$

Moreover, the chronology implied by the relationship between Dvāravatī and Pagan is quite problematic. The earliest date given to the Dvāravatī script is the sixth century, while the latest sample is found in the ninth. ${ }^{46}$ There is thus some 250 years between the disappearance of the Dvāravatī script and the appearance of the first Old Mon inscriptions of Kyanzittha in 1093 and 1098. (Nearly all other inscriptions found in Lower Burma prior to Kyanzittha's Old Mon inscriptions are either in the Kadamba script used by the Pyū to write Pali or Pyū, or in Devanagiri, which has linguistic links to Bengal or Nepal, and most of these are inscriptions on votive tablets. $)^{47}$ It is highly questionable, therefore, that a script that had already vanished in the Mon homeland by the ninth century could reappear completely intact in a culturally and geographically distant place after an interval of nearly 250 years! ${ }^{48}$ Knowledge of writing is not held in suspended animation to be revived in its pristine form ten generations later. The argument for the Dvāravatī origins of the Pagán script suggests that the Mon who were thought to have migrated to Burma from Dvāravatī simultaneously developed collective amnesia regarding their writing system as soon as they crossed over to Burma, and just as suddenly and simultaneously their remote descendants regained their collective memory after 250 years in 
order to hand the script in its original form over to the Pagán kings when they came marching down to conquer Lower Burma in the mid-eleventh century.

That illogic aside, there is not a single Old Mon language inscription written in the Dvāravati (Lopburi) script that has yet been found in Burma. ${ }^{49}$ Had this script been the progenitor of the Pagán script and somehow gone over to Burma prior to the first appearance of written Old Mon in the Pagán script, where is it? Surely, there should be some evidence of it, especially in the nearly 1,200 years that the Mon Paradigm claims the Mon spent in Lower Burma prior to Pagán's conquest of the region

To be sure, the script found on a single undated votive tablet in the Yangon Botahtaung Pagoda relic chamber is said, by Guillon, a Mon specialist, to be in the same "type of script" as that found on the Lopburi pillar, ${ }^{50}$ thought to represent the quintessential Dvāravatī script. That might suggest, although Guillon himself does not claim this, that the Dvāravatī script can indeed be found in Lower Burma, and that literate Mon speakers were living there at the time. However, the Botahtaung text is not in Old Mon but in Pali, a different language altogether representing no particular linguistic, ethnic, or cultural group in Southeast Asia. Thus it cannot be used to suggest that the Dvāravatī Mon had migrated to, or were living in Lower Burma. In addition, it is only a single tablet not shown to have been found in situ, and therefore could have been carried there by anyone. Also, it could have been written by someone in Yangôn who knew how to write in that same script, or the tablet may have come directly from South India, the ultimate source of the script. There is no necessary "source-and-recipient" relationship between the script on the Botahtaung and the Lopburi pillar just because they happen to be in the same South Indian script. ${ }^{51}$ To suggest $a$ priori that the script must have taken that route once again privileges the Mon Paradigm's assumed chronology. If anything, the tablet speaks to the presence in Lower Burma of Tamils knowledgeable in Pali.

Furthermore, because the South Indian writing on the Botahtaung tablet and the Lopburi Pillar is in cursive style, ${ }^{52}$ it is probably derived from the eight-century Vatteluttu script. ${ }^{53}$ Because this cursive style is said to have appeared only by the eighth century in South India, it probably reached Lower Burma first (if one followed the traditional routes from South India to Mainland Southeast Asia), and only subsequently arrived at Lopburi. The Lopburi script, then, could well have been the later of the two to adopt the change that began in South India.

Another reason Dvāravati was not likely to have been the source for the Pagán script is the fact that all dated Old Mon language inscriptions found in Burma are written in the already developed Pagán script; there are no examples in the country of Old Mon having been written in an earlier, less- 
developed stage in that script. This suggests that the Old Mon script of Burma may actually have been derived domestically (from Old Burmese, as we shall see below), or at least owed nothing to the Dvāravatī script.

Perhaps the most serious problem with the Dvāravatī thesis is that the bulk of the written data that has informed the understanding of the Old Mon language of Dvāravatī was not taken from Dvāravatī but from Pagán. ${ }^{54}$ We are told that the main reason for this is that the Old Mon inscriptions of Dvāravatī number only a few (two, if only the stones are counted, more if each epigraph is counted separately), ${ }^{55}$ and as of this writing only seven legible, relatively short, Old Mon inscriptions can be found at Haripuñjaya. ${ }^{56}$ It is on the earlier group of inscriptions-fewer than ten at bestwritten in Dvāravatī Old Mon, per se-along with some domestic silver coins (and/or other inscribed metals) thought to have belonged to Dvāravatī itself ${ }^{57}$ - that the entity known as Dvāravatī and its language has been based. .58

In contrast, if we include those that King Kyanzittha erected in Lower Burma and elsewhere, there are approximately a dozen, very long Old Mon inscriptions that have survived, the linguistic data of which far exceeds those of Dvāravatī and Haripuñjaya. ${ }^{59}$ Because of the quantity and quality of data found in Burma, then, Pagán Old Mon is the basis for most of our information on understanding the Old Mon language itself, and the Pagán script, the basis for accessing that information. Diffloth writes that "the Thatôn Old Mon and the Kyanzittha Old Mon inscriptions are our main source of information on the structure of the Old Mon language," 60 which means-since the "Thatôn Old Mon" of Diffloth is actually Pagán Old Mon—that Pagán Old Mon is the standard by which to study Old Mon in general.

Understandably, Old Mon scholars may not have had much choice in the matter, given the limited number of Old Mon sources. But that does not change the fact that most of our knowledge of Old Mon structure has been taken from eleventh-century Pagán data, not Dvāravatī. What this means is that data was removed out of its context from one historically, culturally, and geographically different and distant place (Pagán), ascribed to another historically, culturally, and geographically different and distant place (Dvāravatī), and then anachronistically used to conclude that the latter was the origins of the former.

As if to underscore the point that no evidence exists linking the Dvāravatī to the Pagán script, neither Luce nor the other advocates of the Mon Paradigm have shown paleographically how the Mon script of Dvāravatī may have evolved into the Burma script of Pagán. Not even a conjecturally reconstructed chart has been published to demonstrate that the thirtythree consonants and fourteen vowels ${ }^{61}$ of the Burma script-excluding tone markers that the Mon language did not use-were derived from the 
consonants, vowels, and nonexistent tone markers of the Dvāravatī writing system. Even if similarities can be shown to exist in their respective consonant-vowel systems - they are "nearly identical" during the Pagán period in any case-it is because both scripts ultimately come from the Sanskrit alphabet. It is not proof that Dvāravatì was the progenitor.

But one could still argue that some relationship must have existed between the Mon speakers of Thailand and twelfth-century Pagán, for after all, there were Old Mon language inscriptions and speakers in Pagán. True as that may be, it does not necessarily mean that Dvāravatī was the source of either. And that it was not helps explain the differences that are known to exist between Dvāravatī Old Mon and Pagán Old Mon, ${ }^{62}$ between the Lopburi script in which Dvāravatī Old Mon was written and the Pagán script in which Kyanzittha Old Mon inscriptions were written, and the two-century gap between the latter two. None of these puzzles had been explained by the Mon Paradigm.

If, then, the people who spoke the Dvāravatī Old Mon language and wrote in the Lopburi script did not move anywhere in particular while the rest of the Old Mon speakers moved eastward, then how and approximately when did the Old Mon language itself get to Burma? What little evidence we have suggests that the Old Mon speakers who eventually made it to Prome and Pagán in the late eleventh and early twelfth centuries were probably the descendants of a splinter group who had separated from the original Dvāravatī population much earlier. Part of this separation may have been triggered by the movement of T'ai speakers southward, splitting the existing Mon population into east and west segments. Or perhaps the tenthcentury Khmer move northwestward pushed Old Mon speakers into Lower Burma by the eleventh. Perhaps both happened. Whatever the answer may be, it is clear that Dvāravatī was not the source of the Pagan script.

\section{HARIPUÑJAYA}

If not Dvāravatī, could the Old Mon script have come from Haripuñjaya? Here as well, there are problems of historicity and provenance. The only historical account in Southeast Asian history that actually speaks of a Mon migration to what may have been Lower Burma is the so-called cholera epidemic. The problem is dating the event; those given by the Northern T'ai chronicles are centuries too early to be of relevance here, while Coedes assigns it to the mid-eleventh century. But we should remember that Coedes's date is not only conjectural, but meant to coincide with Aniruddha's alleged conquest of Thatôn and therefore very much a part of the analytical framework of the Mon Paradigm. There is one other event suggested by an Old Burmese inscription which might have found Old Mon 
speakers in Lower Burma: an alleged battle between the forces of Pagán and Angkor around $1056 \mathrm{AD}$ somewhere in Lower Burma. Old Mon speakers may have been among the levies of Khmer troops from the earlier conquest of the Thailand Rāmanya mentioned in Khmer inscriptions. ${ }^{63}$

However, most Mon scholars knowledgeable about the Haripuñjaya script contend that the Old Mon script went exactly the other direction, from Pagán to Haripuñaya. ${ }^{64}$ As one scholar put it: "There is evidence to the effect that the people of Haripunjaya brought the Mon and the Burmese [i.e., Pagán] alphabet to their city and adapted it in northern Thailand. It survives to the present day." ${ }^{5}$ Even the Northern T'ai chronicles, doubtful though the dates are, state that after the epidemic, some of the refugees returned to Haripunjaya, probably taking the script back with them. Luce himself agrees that the script of the Haripunjaya inscriptions "clearly derives in the main from that of eleventh- to twelfth-century Burma." ${ }^{66}$ Diffloth confirms at least the late period of the Haripunjaya inscriptions, noting that most of the well-known ones date to the thirteenth century. ${ }^{67}$

What all this evidence suggests is that the Old Mon script went from Pagán, to Thatôn, and from there to Haripuñjaya, and chronologically in that sequence as well. This means that the direction in which the script moved had nothing to do with the history of the Old Mon script at Dvāravatì itself. ${ }^{68}$ Rather, it appears that Dvāravatī has been an inadvertent "red herring" all along and was never part of the picture regarding the Pagán Old Mon script in the first place.

My tentative explanation for the differences in the history of the Old Mon script of Burma and that of Dvāravatī is quite simple: they were taken from two different writing systems that appeared in Southeast Asia at two different times. The first, representing the Old Mon script of Pagán, was derived from Old Burmese via an earlier Pyū script from perhaps the fourth century, as is discussed below, while the second, Dvāravatī's, probably came from South India's Pallava script, later superceded by the Vatteluttu of the eighth century. With the decline of Dvāravatî in the ninth century, its script also disappeared in that place, but found its way towards the northeast to Chanasa and Vientiane, while its language continues as Nyah Kur to the present.

\section{The Pyū Connection}

Since the Mon connection regarding the origins of the Pagán script is not analytically, historically, or paleographically viable, what alternatives are left? These cannot simply be theoretical possibilities, but must exist within the context of Burma's known history. 


\section{SOUTHWEST OR SOUTHEAST INDIA?}

The only option that meets the historical requirement seems to be the Pyū connection. I should make clear that my argument is less an attempt to trace the origins of the Pyū script per se than it is to trace the Pagán script from the Pyū. I withhold judgment on whether the old Finot thesis that the Pyū script came from Kadamba is correct or the more recent Falk thesis that it came from Andhra. ${ }^{69}$ Rather, the focus here is the Pyū connection to the Pagán script.

This Pyū connection, in contrast to the Mon, has not had much exposure in English. It is largely the work of one lone Burmese scholar, who, during the generation in which the Mon Paradigm became entrenched and institutionalized, wondered about the thesis that the Burma script was derived from the Mon of Thatôn only after 1057 via Dvāravatī. ${ }^{70}$ That person was $\mathrm{U}$ Tha Myat, a modest individual writing mostly in Burmese. As a result, he was, for the most part, ignored by western scholars. ${ }^{71}$ In several short but detailed paleographic studies on the evolution of the Pyū script via its Indic predecessors, which he based on data taken from original Pyū epigraphy and published works on Indic scripts, Tha Myat showed how the Pyū script evolved from Kadamba, a script belonging to Southwestern India, and went from there to Śrī Kṣetra Pyū, to Myazedi Pyū, to the Burma script found on the Pagán inscriptions, and finally to the palm-leaf manuscripts of Burma. ${ }^{72}$

To be sure, there had been important groundwork done prior to U Tha Myat's work. In 1897 two gold plates were found at Maung Kan village near Prome. They were said to have been inscribed in the Pyū script expressing the Pali language and were first edited by U Tun Nyein, the government translator. ${ }^{73}$ Then in 1912 Finot published an article in Journal Asiatique regarding a Pali stone inscription written in Pyū script discovered at the Bawbawgyi stupa, Śrī Kșetra, and, for perhaps the first time, the script was recognized as having clear affinities to Kannada's Kadamba. ${ }^{74}$ By the late 1920s Duroiselle had discovered the Khin Ba mound treasure trove, which included a gold-leaf manuscript of twenty leaves written in Pyū in the Pali language. ${ }^{75}$ In the 1930s Duroiselle also recognized that the script used at Kyôntu near Pegu was what he called Telugu-Kanara, "closely resembling the Kadamba type." 76 And of course, we cannot forget the pioneering work done by Blagden, who deciphered the Pyū script that had been "dead" for nearly eight centuries. In other words, whereas most early Burma scholars recognized that the Pyū script came from Kadamba ${ }^{77}$ before U Tha Myat's publications, none suggested that the Pyū script might have been the source for the Pagán and hence the Burma script. That was U Tha Myat's contribution. But it ran directly counter to the dominant thesis of the time: the Mon Paradigm. 


\section{Halin, Śri Kșetra, And PagÁn}

At Beikthano, the earliest radiocarbon-dated Pyū site so far excavated, an inscription in Brāhmī datable to the second century AD has been found, apparently written in the Pali language with the phrase Samgha siri. ${ }^{78}$ We are not told which form of Brāhmī it is, although it is probably the evolved Brāhmì of South India. Stargardt suggests the closet antecedent may be the letters used by the southern Ikșvāku Dynasty, whose inscriptions are most common in Nagarjunakonda. And since the letters seem to have incorporated what she called a "chronological mixture of styles," the latest, from the fourth century, this sample probably belongs to that period. ${ }^{79}$ This also suggests that during that period the Pyū had not quite fully developed their own script and were still using Indic ones to express complex religious sentiments.

But the main epigraphic basis for U Tha Myat's work were the Pyū inscriptions proper, which at the time he conducted his research numbered approximately twenty-five separate ones. ${ }^{80}$ By Pyu "inscription" is meant the writing system used to write the Pyū and sometimes Pali languages, which later became popularly known as the Pyū script. ${ }^{81}$ The earliest Pyū language inscriptions per se were probably found at Halin. Although Halin itself first appears about the first century AD according to radiocarbon results, its script dates to approximately the fourth century AD. ${ }^{82}$ It is much earlier than the seventh century, to which Luce had dated it, for reasons bolstering the Mon Paradigm. ${ }^{83}$ In fact, Halin writing predates by at least two hundred years the best paleographically dated evidence of Old Mon writing at Dvāravatī ${ }^{84}$ which is assigned at the earliest to the sixth century for the Nakhon Pathom and the eighth century for the Lopburi inscriptions. ${ }^{85}$ Indeed, Stargardt feels that the earliest Pali text written in an Andhra script so far discovered in all of South and Southeast Asia is to be found in Pyū culture. ${ }^{86}$

In what U Tha Myat considers to be fourth-century Pyū, three lines of writing appear found on a funerary stone that records the builder to be one "glorious" Tubahi [who is?] "glorious" Dawintinmrin's son, [who is?] grandson of one Nagukanaw." ${ }^{87}$ These do not appear to be names of royalty but perhaps belonged to people of some stature nevertheless. Another stone inscription found at Halin during the 1960s contains royal titles beginning with Śri Trivigrama. It has seven lines of Pyū and seven lines of "interlineal" Brāhmī, suggesting that the Brāhmī may have been the parent script, still present and functioning. ${ }^{88}$ Another small stone slab has eight short lines of Pyū with no Brāhmī, on which one can make out Mahādevi Śrī Jatra. As mentioned in Chapter Two, a fourth stone fragment has seven Pyū letters saying Sri Jatrādevi ${ }^{89} \mathrm{U}$ Tha Myat dates the letters of the stone with the Maha devi Śri Jatra on it to the fourth and fifth centuries AD. ${ }^{90}$ 
These inscriptions suggest that by the middle of the Halin period, the Pyū culture had developed its own writing system, probably taken from one of the Brāhmi evolutions. It probably received the script directly from the ancestor of Telegu-Kannada or Pallava-Grantha around 300 AD, when the first inscriptions in Southeast Asia with this script appeared, ${ }^{91}$ whereas, as noted above, the cursive Pallava script on the Lopburi pillars may have developed only in the eighth century and if so, must have been a subsequent import from South India when the Pallavas emerged as a major force in South and Southeast Asia from the sixth century onward. ${ }^{92}$ This means that even if at one time in India the ancestor of Telegu-Kannada was much the same as Pallava-Grantha, by the time the Lopburi inscriptions appeared in the seventh or eighth centuries, the early similarities were all but gone. That is probably the reason that Luce noticed such differences between the Pyū and the Dvāravatī scripts.

It is true that the largest number of Pyū inscriptions are found at seventh century Śrì Kṣetra and not Halin, most of them thought to have been inscribed between the sixth and eighth centuries AD or earlier. ${ }^{93}$ Of them, the most celebrated is the gold manuscript noted above, whose contents are extracts from the Abhidhamma and Vinaya Pitaka. ${ }^{94}$ Votive tablets with similar extracts from the Abhidhamma in Pyū script have also been found there, along with ordinary statements made by donors regarding their good deeds. ${ }^{95}$ In another find at Śrī Kṣetra, the four Theravāda Buddhas of this kalpa were mentioned by name on a silver cylindrical reliquary. Finally, Pyū was inscribed on royal funerary urns, all of them with dates, three belonging to the seventh century and one to the early eighth. ${ }^{96}$

The Pyū/Pali script has also been found in Lower Burma, at Tadagale, ${ }^{97}$ Yangôn, which Luce assigns to around the seventh century, ${ }^{98}$ and at Kyôntu, about twenty miles northeast of modern Pegu. Writing in what appears to be Kadamba script on bricks that had distinctive Pyū mason marks similar to those found at Old Prome and Pagán has also been found in Lower Burma ${ }^{99}$ A terracotta votive tablet written in the same Pyū script has been uncovered among the artifacts of the relic chamber of the Pagán Shwéhsandaw temple attributed to King Aniruddha. ${ }^{100}$ One of the latest and most useful of Pyū texts, of course, are the already much discussed Myazedi Inscriptions of 1112-1113. Inscriptions in Pyū script have also appeared in Thandway (Sandaway) on the coasts of the Bay of Bengal in southern Arakan, ${ }^{101}$ while the latest are at Pagán, said to belong to the thirteenth century. All this adds to the already large corpus of architectural, art historical, numismatic, and archaeological evidence that suggests it was the Pyū, not the Mon, whose culture dominated in Burma during the centuries preceding the rise of the Pagán kingdom and most likely contributed to the writing system of Pagán. ${ }^{102}$ 
U Tha Myat is also the only one of his generation who made an attempt to graphically demonstrate the evolution of the Burma script from known samples, something neither Duroiselle nor Luce did. Duroiselle tended to assert his views without explanation or documentation, except of the most general sort, while Luce accepted Duroiselle's conclusions without much comment, except to add Dvāravatī as the source of the Pagán script. As far as I can tell, U Tha Myat was not trained as a linguist, but neither was Luce. Besides, since U Tha Myat's study of comparative Indic, Pyū, and Burmese paleography is the only one of its kind, the result of a lifetime of devoted study, the data he left behind are rare and useful.

More specifically, U Tha Myat's Mon-Myanma Akkhaya Thamaing (History of the Mon-Burmese alphabet) graphically demonstrates the evolutionary path taken by all the vowels, consonants, and numerals of Pyū leading up to the Burma script. For the most part his material is taken from actual dated epigraphy. ${ }^{103}$ He begins with Brāhmī, then proceeds in sequence through Kusana, Gupta, Grantha, Kadamba, Maung Kan Pyū (sixth-century Śrī Kșetra), ${ }^{104}$ Khinba Pyū (seventh- to eighth-century Śrì Kșetra), Myazedi Pyū (twelfth-century Pagán), the Burma script (Burmese and Mon) on the inscriptions of Pagán, to conclude with the script on palm-leaf manuscripts. On the whole U Tha Myat's evolutionary scheme seems correct, and in virtually every case the immediate predecessor to the Burmese letters is quite clearly Pyū, not Dvāravatī Mon. ${ }^{105}$

There are a few minor puzzles in his evolutionary scheme after Śrī Kṣetra, especially if it implies a direct, linear development between Myazedi Pyū and the Pagán Burma script, for as we shall see below many Old Burmese inscriptions preceded the Myazedi Inscriptions, so that Myazedi Pyū cannot have been the immediate predecessor of Pagán Burmese. This suggests that even U Tha Myat may have been influenced by the Mon Paradigm's claim that the Myazedi Inscriptions were the first evidence of written Burmese, an erroneous conclusion that has led to many mistakes. As we shall see in Chapter Eight, the Mon Paradigm scholars could not entertain the possibility that the Old Burmese script on the Myazedi Inscription (and hence the Burma script) could have come from Pyū without destroying their main premise, so that their intellectual options were hindered by their own thesis.

I am suggesting, and the paleography shows, that the Burma (Pagán) script was most likely derived from Śrī Kṣetra Pyū much earlier than the time suggested by $\mathrm{U}$ Tha Myat, ${ }^{106}$ that is, well before the twelfth-century Myazedi script. The development of the consonant $k a$ in his chart, for example, has two additional conjectural stages between the $k a$ of sixth-century Maung Kan Śrī Kṣetra Pyū and the Pagán $k a,{ }^{107}$ but they are not based on actual epigraphy. The examples of other vowels and consonants in his evo- 
lutionary chart had been taken from actual epigraphy and pose no detectable problems. We also notice immediately that the consonant kha of the Pagán script appears to be a direct descendant of the kha of sixth-century (Maung Kan) Pyū rather than of its later stages (eighth-century Śrī Kṣetra and twelfth-century Myazedi Pyū) which are a bit different, at least as shown on U Tha Myat's graph. This suggests an earlier and direct borrowing from sixth-century Śrī Kșetra. ${ }^{108}$ In fact, in some cases, such as the ga and gha, and also the $j a$, the closest ancestor is Kadamba, which skips even the Srì Kṣetra phase, while the nga is closest to the ultimate source: Brāhmī. Although I have no explanation for the apparent direct link of the nga consonant to Brāhmī (other than its simplicity limiting any significant changes), the Burma script apparently borrowed from the Pyū script much earlier than the twelfth century, perhaps after the decline of Śrī Kṣetra as political and cultural center. This explains part of the apparent differences between the Pyū script on the Myazedi Inscription and the other three languages written with the Burma script, although Robert Shaffer, a TibetoBurman linguist, has long held that Myazedi Pyū was not as different from the other three scripts as had been made out to be. ${ }^{109}$

Still, it would help if some evidence of the Burma script prior to the tenth and eleventh-century Old Burmese inscriptions could be found, for U Tha Myat's paleography and my contention would be on much more solid ground if we could verify the "missing links" of the $k a$ consonant. The answer may actually reside with the Old Burmese inscriptions we already possess, particularly those that have been rejected as "impossible" by the Mon Paradigm, especially an early (1035 AD) inscription erected at Bodhgayā, India, a subject to be discussed in Chapter Eight.

There are also linguistic affinities between Pyū and Burmese that have had an effect on the Burma script—as both belong to the Tibeto-Burman family_but are not found in Mon and Burmese or Pyū and Mon. We can see how the Pyū and Burmese scripts adapted tones ${ }^{110}$ to a "toneless" Sanskrit alphabet, not a reason for much concern among those speaking nontonal Mon. ${ }^{111}$ Blagden noticed a "wide range of tones," nearly eight markers, ${ }^{112}$ a number which may have been necessary since the Pyū (at least according to Luce) used two scripts, ${ }^{113}$ one perhaps for writing toneless Pali and the other for tonal Pyū, one arriving earlier and the other evolving later.

Moreover, Pyū vocabulary, even according to Luce, is far closer to Burmese than to any other single language in Burma of the time, ${ }^{114}$ particularly when contrasted to Mon. Not only are there similarities of cultural terms, which is expected given their long history together, but also of kinship and social terms, implying a much closer ethnolinguistic connection. Indeed, 
Blagden so much as said that the Myazedi Inscriptions revealed the "former existence of a $[\mathrm{Py} \overline{\mathrm{u}}]$ nation and language which have apparently been completely absorbed by the Burmese ...." 115 In the entire glossary provided by him and gleaned from the Myazedi Inscriptions, there is only one word in Pyū that may have had a connection to a probable Mon word-the word for "gold"-hardly a term that suggests close sociocultural or ethnolinguistic ties.

In contrast, many important words in both Pyū and Burmese are identical, such as "son," "wife," the numerals one, three, and eight, "grandchild," "to die," "to give," "to do," "myself," "year," "city," "likeness," "this," "was," "violence," "to be named (or) called," "that," "this," "shape," and the possessive affix. Or the words are nearly identical, such as "to pour," "dedication," "to donate," "oppress," "my," "to make," "to be sick." Also similar are particles following verbs and numerals, particles used to connect numerals with nouns or used after words in "the genitive relation," verbal affixes, and plural affixes. ${ }^{116}$ Even the structure for making verbs negative is common to Pyū and Burmese. ${ }^{117}$ Especially noteworthy are the above mentioned kinship terms such as "son" and "grandchild," or near-kinship ones such as "wife," as well as a most important political and administrative word-“city," "capital," "kingdom,"-in Old Burmese prañ and in Pyū pri:, still used today as "country" or "nation." Their affinity to each other suggests a closeness between the Pyū and Burman peoples well beyond geographic propinquity or casual historical interaction. It is a relationship not found between any other two major cultural groups at the time in Burma.

It is true that there are also affinities between Mon and Burmese vocabulary. ${ }^{118}$ But to suggest, as some have, that kinship terms such as the Burmese word for "widow" (kmay) came from Mon ${ }^{119}$ is unproven and quite absurd, for one of the last things to be borrowed from another culture are kinship terms. Besides, are we to believe that Burmese had no widows before they met the Mon? Or perhaps the Mon word for "widow" was intrinsically so much better than the Burmese that an entire ethnolinguistic population simultaneously changed its word for it and did it so thoroughly that not a trace of its vestige survives?

The relevance here is not the mere fact of borrowing, but a question of when and which way these words may have gone. So far, no one has demonstrated that any borrowing occurred between Burmese and Mon speakers during the Pagán period, but only subsequently, when, after the development of a Mon state in Lower Burma in the late thirteenth century, Burman-Mon contact was regular and constant for nearly 700 years. Nor has it yet been proved that certain words that are common to both necessarily came from the Mon rather than from the Burmese. The assumption that 
these loanwords traveled only one way, in this case from Mon to Burmese, and did so early, once again privileged the Mon and bolstered the Mon Paradigm.

Linguists tell us that there may be several different ways for words to become loanwords or appear connected. Blagden put it well when he wrote that if there arose a question of a particular Burmese word alleged to be connected to, say, a Chinese word, then it could be that (a) the word in Burmese may have come from Chinese, or (b) the word in Chinese may have come from Burmese, or (c) the word may have been borrowed from some third source, such as Sanskrit, or (d) it may have been derived from the original stock of the family to which both languages belong (SinoTibetan), or (e) the word may not be related at all, but coincidentally sound similar. ${ }^{120}$

As Mon and Burmese come from different language families, "d" can be eliminated, but there are four other ways in which loanwords, if that is what they are in the first place, may have been derived, not the least of which is that they may coincidentally sound similar. ${ }^{121}$ Other than option "a" and "b," which is most probably what happened once the two cultures met, option "c" (borrowing from a third source) is also relevant. And even if one can show with linguistic principles that Mon loanwords are present in Burmese today, it cannot in any way even suggest that the origins of the Burma script used in the eleventh century also came from the Mon or that the borrowing occurred in the Pagán, rather than much later in the Ava and Pegu periods. The assumption of an earlier Mon civilization in Lower Burma, once again, has been the basis for such conclusions.

One of the difficulties in attempting to decipher approximately when the Pyū script was adopted by Burmese speakers is the archaism of the Pyū script. Most of the letters of the Pyū alphabet, whether taken from the Maung Kan gold plates of the sixth century, or those of eighth-century Śri Kșetra, or even the early twelfth-century Myazedi Inscriptions of Prince Rājakumār, are virtually identical. ${ }^{122}$ As Luce himself put it well, over seven centuries the Pyū script changed but little, ${ }^{123}$ even if the language itself may have. ${ }^{124}$ That is precisely the reason one finds a sixth or eighth-century script on the early twelfth-century Myazedi Inscription. Although this raises concerns about the ability of paleography to determine the age of certain, unchanging scripts with any precision-in part because its methodology consciously seeks change and its conclusions are based on it-it is also paleography on which we must depend, even if in conjunction with other historical evidence.

Not only did the Pyū script not change over approximately seven centuries, but by the time of the Myazedi Inscriptions it was considered archaic 
when compared with the Indic script from which it originally came. Blagden noticed that twelfth-century Myazedi Pyū used forms that were obsolete in South India, some having fallen out of usage by the fourth century AD. ${ }^{125}$ This suggests that the Pyū must have adopted the Kadamba or Andhra script before those features became obsolete. This is also about the same time that the earliest Halin Pyū writing appears. ${ }^{126}$ Thus the unchanging character of the Pyū script, and its archaism particularly, may allow us to date the period of its inception even better.

On the other hand, any definition of archaism depends on the user's viewpoint. Even though the parent South Indian script may have gone through some changes-such that vestiges of it found in Pyū were no longer used in India and were therefore considered "obsolete" or "archaic"-the Pyū script in Burma itself had not changed. In other words, even if for a South Indian, certain features of the Pyū script appeared archaic, for a Pyū, it was current. And since it was still current to the Pyū, they kept using it for several more centuries, making it appear, as Luce put it, "archaic from the start." 127

That, however, does not explain why the Pyū script did not change thereafter. And this is where history again comes in. The probable explanation lies in the common history of the Pyū and Burmans after Śrī Kșetra's decline, which may have occurred after Sīhavikrama's death in 718. ${ }^{128}$ By about 800 AD, the Pyū kingdom seems to have come under Nanchao domination, ${ }^{129}$ the Chinese sources stating that "through its military strength and territorial proximity Nanchao has always held the Pyū kingdom in control," to the extent the leader of Nanchao took the title of "P'iao shin" (lord of the P'iao). ${ }^{130}$ Perhaps because of Pyū resistance, their kingdom was said to have been "looted and plundered" by Nanchao in the first half of the ninth century, ${ }^{131}$ shortly after which the Burmese speakers emerged in the historical records as leaders of Upper Burma, subsequently inhabiting the same general settlement areas that the Pyū had once occupied. Whether or not the Burmese speakers were part of the "advance guard" of the Nanchao kingdom, as some Burma scholars assert ${ }^{132}$ is not clear. Equally possible is the option that the Burmese speakers were already in the plains of the Irrawaddy, integrated with the Pyū, as suggested by their close sociolinguistic ties. That there were also special linguistic and cultural ties between the Yi (Lolo) people-one of the ethnic groups said to have been part of the Nanchao kingdom-with the Pyū and Burmese also seems reasonable enough. 133

In any case, as the new leaders of a state attempting to integrate numerous ethnic groups and their languages and cultures into one entity, the Burmans would naturally have made their language the lingua franca 
and their script the standard for the kingdom. When the Pyū lost their place to the Burmese speakers as leaders of state and society, it would have further accelerated the decline of the Pyū language, especially for public use. Once the spoken language was no longer used widely, the same fate would befall the written one, which, not surprisingly, all but disappeared in the epigraphic record as the script of state. ${ }^{134}$ The Pyū language and script had become moribund and thus "frozen in time," which explains why the script hardly changed after eighth-century Śrì Kṣetra and why it was virtually the same when it was finally written again on the twelfth-century Myazedi Inscriptions.

From the mid-ninth to the mid-tenth century the power of the Burmese speakers was consolidated. They established themselves at the walled city of Pagán around the late tenth or early eleventh centuries, as confirmed by radiocarbon analysis and epigraphy, a period in which at least two verifiable kings, Saw Rahan and Kyaung Phyu Min, Aniruddha's grandfather and father reigned, if not ruled. ${ }^{135}$ However, the early ninth century was not the end of the Pyū people, their culture, or even their writing system, for they continued to live in Burmese society at Pagán and even Ava for several more centuries, very likely contributing their skills in gold, wood, and silver crafts to the Burmans. ${ }^{136}$ Their language and script continued to be used, albeit on a very irregular basis, as, for example, the terracotta votive tablet with six lines in Pyū script found in the relic chamber of the Shwéhsandaw Pagoda attests. ${ }^{137}$ Of course the Pyū script and language on the Myazedi Inscriptions also testifies to their presence, or at least to someone with knowledge of both, in the early twelfth century, while another Pyū inscription is assigned to the late thirteenth century. ${ }^{138}$ And, as noted in Chapter Two, there are epigraphic references in Old Burmese during the Pagán and Ava periods to Pyū as individuals and groups living there. ${ }^{139}$

Thus there were present at Pagán people who could still write in the old language, just as there are those today who can read and write Old Burmese (or Latin and Old English). The "archaism" of classical Latin or Old English compared with modern English no more suggests the absence of a paleographic relationship between them than those between Pyū and the other three scripts on the Myazedi Inscriptions simply because they might look different to the untrained eye. But it was more than that: the role that the Pyū script played on the royal Myazedi Inscriptions-that of a "classical ancestor" providing the prestige of tradition to the text and its contextis perhaps similar to the use of classical Latin today in commemorative inscriptions in English-speaking societies. One thing is certain: no evidence of a comparable relationship between the Old Mon writing system of Dvāravatī as a "classical ancestor" and the other languages of Burma can be found in the epigraphic record. Indeed, the Pyū-Burman cultural integra- 
tion occurred probably two centuries before first proven contact between Burmese and Mon speakers, for only with Pagán's expansion into Lower Burma in the mid- to late eleventh century is there any epigraphic evidence to even suggest the latter encounter. It was only then that the Burma script, already functioning in Upper Burma, could have been given to the Mon of Lower Burma for the first time, which in large part explains why Old Mon writing cannot be found earlier than the late eleventh century anywhere in the country.

In sum, not only is there paleographic evidence that the Pyu gave their script to the Burmese speakers, resulting in the Burma script, but it is supported by their probable history together, revealed by their affinity in language, their patronymic linkage system, their arts and crafts, their architecture, their shared Indic conceptual system, their cosmological urban designs, their irrigation technology, and their settlement locations, all discussed in Chapter Two.

\section{Conclusion}

The Mon Paradigm's case regarding the Burma script has hinged on the same assumptions from which it began: that Mon civilization in Lower Burma was older than Burman civilization in Upper Burma in every instance and that the mechanism by which this putative earlier civilization was transferred was the alleged conquest of Thatôn by Aniruddha. Perhaps it may have been the lack of scientific data on the Pyū culture that kept earlier scholars from considering the Pyū option more seriously, although as we have seen, most of the relevant discoveries had been made by the late 1930s. Certainly, Mon Paradigm proponents never appeared to consider that the reverse could have occurred: that the Old Mon writing system might actually have been borrowed from the Old Burmese of Pagán. Neither the written Mon evidence, its analysis, and its documented history, nor the written Burmese evidence, its analysis, and its documented history has led, as it should have, to the conclusion that the Burmese borrowed its writing system from Mon. Rather it was as Duroiselle stated in 1919, "the greater antiquity of Talaing civilisation [had been] accepted on every hand."

The century-old thesis that the Old Mon writing system was responsible for the Burma script is simply no longer viable. There is no historical record of Mon immigration from Dvāravatī to Lower Burma, no evidence of written Mon in the Dvāravatī script in Burma, no proven or demonstrated paleographic relationship between the Old Mon writing system of Dvāravatì and that of Pagán, and no dated Old Mon inscriptions other than those in the Burma (Pagán) script in the entire country.

In contrast, there is paleographic evidence of the link between the Pyū 
script of both Halin and Śrī Kṣetra and the Pagán script, close cultural and linguistic ties between Pyū and Burmese speakers at least two to three centuries prior to the latter's first contact with Mon speakers, and several centuries of political and historical contact and integration between Pyū and Burman. Therefore, the Burma script most likely evolved from the Pyū, and the direction taken by the Burma script was probably much like that of early civilization itself in Burma: north to south, interior to the coasts, and hence Pyū to Burman and Burman to Mon, not the reverse. 